Historic, Archive Document

Do not assume content reflects current scientific knowledge, policies, or practices. 



\title{
Fall 1925 and Spring 1926
}

\author{
潾 \\ WHOLESALE \\ TRADE LIST \\ 潾-
}

-OF THE-

\section{Vincennes Nurseries}

\section{W. C. REED \& SON \\ Vincennes, Ind.}

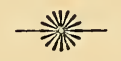

Usuai 'Terms and Conditions

Boxing At Cost

\section{REFERENCES}

First National Bank.

American National Bank

Mercantile Agencies Any Business Firm In Vincennes.

We are One of the Largest Cherry Growers In the U.S.

\section{LOCATION AND SHIPPING FACILITIES}

We are located in southwestern Indiana, 150 miles from St. Louis, 190 miles from Cincinnati, 235 miles frcm Chicago, 210 miles frcm Nashville. Railways: B. \& O. S. W., C. \& E. I., Big Four and Pennsylvania Lines. Being located on the Main Trunk lines east and west and north and south, have splendid through freight service, also express. 


\section{CHERRY-Two Year}

$X X$ inch and up 5 to $6 \mathrm{ft}$.

11-16 up first class 5 to $6 \mathrm{ft}$.

9-16 to $11-164$ to $5 \mathrm{ft}$.

7-16 to $9-1631 / 2$ to $4 \frac{1}{2} \mathrm{ft}$

Special prices on car lots.

Dye House

Early Richmond

English Morrello
May Duke

Montmorency

Wragg
Royal Duke

Late Duke

Gov. Wood, 20c extra

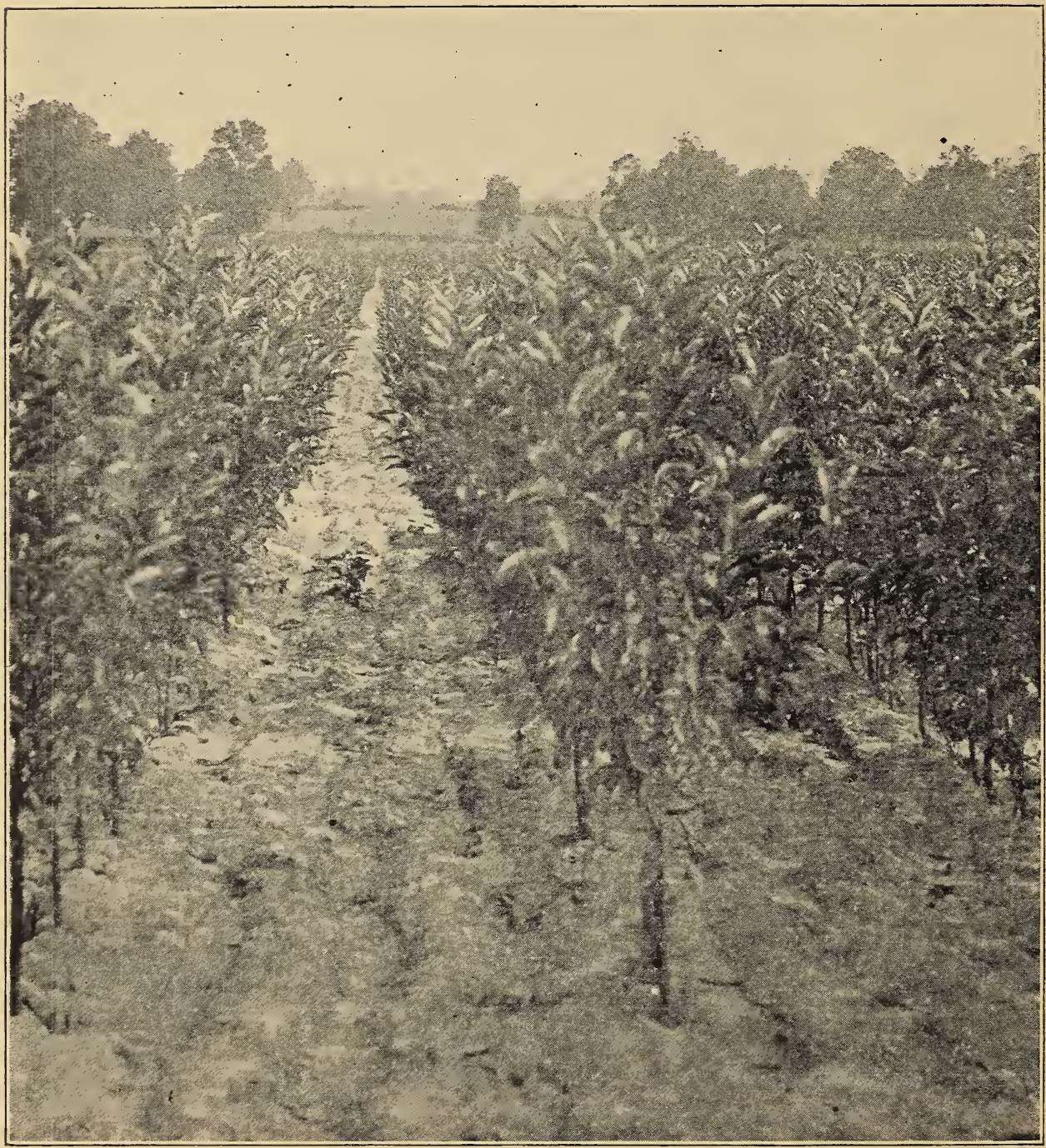

\section{Showing Block of Cherry Coming One Year Old} CHERRY-One Year Sweets

5 to $7 \mathrm{ft}$. largely branched

Per 100

4 to $5 \mathrm{ft}$. partly branched. $\$ 40.00$

3 to $4 \mathrm{ft}$. mostly whips 30.00 Bing all sold Bik. Tartarian Lambert Windsor Schmidts 20.00

Gov. Wood Sweets are extra fine unusuallv well branched.

Windsor

Nelson Blk.

Royal Anne 
11-16 up 4 to $5 \mathrm{ft}$.

9-16 to $11-1631 / 2$ to $4 \frac{1}{2} \mathrm{ft}$.

7-16 to 9-16 about 3 to $4 \mathrm{ft}$.

5-16 to 7-16 2 to $3 \mathrm{ft}$.

Early Richmond

Montmorency

Wragg

Dye House

English Morrello

\section{APPLE-Two Year}

Per 100

11-16 up 5 to $7 \mathrm{ft}$

9-16 to 11-16 4 to $6 \mathrm{ft}$.

Double Worked Grimes 4-6 ft.

York Imperial

Rome Beauty

Grimes Golden

Early Harvest

Turley

Wealthy
Staymans

Rambo

Delicious

Sweet June

Wine Sap
Gano

Banana

Whitney

Hyslop

Golden Sweet

\section{APPLE_One Year Buds}

4 to 6 feet 9-16 up

3 to 4 feet $7-16$ to $9-16$

Gano

W. Banana

Benoni

Wealthy

Ark. Black
York Imperial

Maiden Blush

Rambo

Yel. Transparent

Delicious

Grimes Golden

Duchess

Rome Beauty

Jonathan

Wine Sap
Duchess

Benoni

Jonathan

Maiden Biush

Yel. 'Transparent

PEAR_STANDARD—One Year

Per 100 $\$ 25.00$

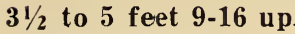
8000 Bartlett,

1700 Clapps Fav. 500 Wilder

1700 Flemish Bearty

4000 Keiffer
2200 Seckel
400 Koonce
600 B. D. Anjou

4000 Keiffer 400 Koonce 600 B. D. Anjou
300 Lawrence

1000 Duchess

50. Vermont Beauty

300 Garber
Staymans

Hyslop Crab

Turley

\section{EUROP}

$31 / 2$ to 5 feet Budded On Myrobolan.

3000 Shopshire Dams

360 Abundance

350 Red June

700 Burbank
Grand Duke

650 Grand
475 Monarch

1600 Bradshaw

3000 German Prune
1150 Shippers Pride 2500 Lombard

450 Imp. Gage

575 Riene Claude

\section{PEACH-One Year}

Per 100

400 Moores Artic

2500 Fellemberg

265 Satsuma

225 Wickson

$X$ X 11-16 up 5 to $6 \mathrm{ft}$.

Per 100

$\$ 25.00$

9-16 up to 4 to $6 \mathrm{ft}$.

20.08

7-16 to $9-1631 / 2$ to $5 \mathrm{ft}$.

2 to $3 \mathrm{ft}$

Elberta

Early Elberta

J. H. Hale

Shippers R. Late

$\begin{array}{ll}\text { Blood Cling } & \text { Mayflower } \\ \text { Henrietta } & \text { Hooser Cling } \\ \text { Red Bird } & \text { Stump } \\ \text { Late Crawford } & \text { Champion }\end{array}$

QUINCE-Two Year

3 to 4 feet

Rochester

Orange Cling

Krummells

Heath Cling

4 to 5 feet

Downing 
Eldorado

\section{SPECIAL NOTICE.}

Cherry Growing being our specialty we are prepared to furnish Cherry Trees in car lots or by the hundred thousand. Quality was never better, foliage is perfect which means vitality. Please submit list of wants on large lots for special prices. Personal inspection invited. BOXING CHARGES

BOXING CHARGES-Charges are made as low as possible for well made boxes, paper lined:

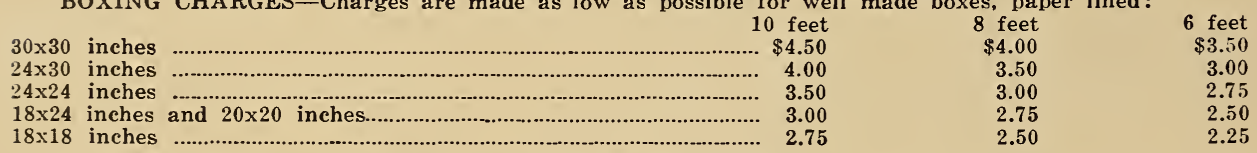

\section{TO THE TRADE}

In presenting our 34th Annual Trafle List, we wish to thank our many customers for the liberal trade extended us in the past and to assure you of our appreciation of your patronage, which we shall make every effort to merit.

We urgently request correspondence and trial orders from new customers, feeling confident that you will be pleased with our stock and method of doins business.

Storage-Our modern Storage Buildings are especially designed for handling Nursery Stock in the best possible manner, enabling us to get the stock to our customers in prime condition. You should consider this in buying.

Stock Handled Under Cover-We have the exposure of stock reduced to the minimum. After digging, all stock is immediately sent to our large packing house where it is graded, packed and handled under cover.

Everything offered is young, thrifty, well-grown stock and graded to the highest standard.

\section{TERMS AND CONDITIONS}

SHIPPING-Please give shipping directions, whether by frieght or express, also route. If no directions are given we will forward to the best of our judgment, without assuming responsibility, as iAll Goods Travel at the Purchaser's Risk and Expense.

TERMS-Gash or satisfactory security, except we extend the usual terms of credit, to known responsible nurserymen. Orders to be sent C. O. D. should be accompanied by one-fourth' cash to receive prompt attention.

PRICES-The quotations in this list are for the wholesale trade only, and limited to the Fall of 1925. Should prices change either higher or lower, during the season, the prices made at the time the order is accepted are expected to stand. All prices are for goods in Nursery, packing extra.

RATES-Fifty trees, of not less than ten of a variety at thousand rates. Long list of varieties of a few trees of a kind subject to higher prices. All trees above the 7-16 to 9-16 grades are tied in bundles of ten in grading. Order tens or multiples of ten of a variety as far as possible.

CAUT'ION-We accept all orders on the condition that they shall be void should injury befall our stock from frost, hail, fire or other causes over which we have no control.

GRADES-We grade carefully, in some cases by caliper, in others by height. When graded by both caliper and height, the caliper must govern.

GUARANTEE OF GENUINESS - If any nursery stock, etc., proves untrue to description under which it is sold, we hold ourselves in readiness, on proper proof, to replace all such nursery stock, etc., that may prove otherwise, or refund the amount paid, but we shall in no case be liable for any sum greater than the amount originally received for said nursery stock. goods.

CLAIMS - No claims for errors or discounts allowrd inless made within ten days after receipt of 